\title{
Is Camfranglais a New Language? A Review of Current Opinions
}

\author{
Valentine Njende Ubanako ${ }^{1}$ \\ ${ }^{1}$ Department of Bilingual Studies, The University of Yaounde 1, Cameroon \\ Correspondence: Valentine Njende Ubanako, Department of Bilingual Studies, The University of Yaounde 1, \\ Cameroon.
}

Received: September 29, 2020; Accepted: March 3, 2021; Published: March 10, 2021

\begin{abstract}
The language-contact situation in Cameroon, where hundreds of ethnic languages coexist with two official languages and a number of lingua francas, continues to evolve and to produce new usage trends and patterns. One of the outcomes of the dynamism of the linguistic situation in Cameroon is the emergence over the last three decades or so of a new linguistic phenomenon that some researchers have styled "Camfranglais" for the simple reason that it comprises a combination of elements drawn from Cameroon indigenous languages ("cam"), from French ("fran"), and from Pidgin English ("anglai"). What precisely this French acronym refers to in linguistic terms remains fairly controversial as some researchers see in this phenomenon the emergence of a new language while other evidence suggests that 'Camfranglais' is certainly a new speech form but not a new language in the strict sense of the term.

This paper sets out to review some of the current opinions about Camfranglais with a view to determining if Camfranglais can be considered a language in its own right or simply as a new speech form which can be said to form a continuum with mainstream Cameroon English. It equally highlights the complexities that render this linguistic phenomenon so elusive to definition.
\end{abstract}

\section{Introduction}

Camfranglais is a hybrid language used in Cameroon, which has developed from the contact between Cameroonian indigenous languages, Pidgin English, English and French. It is widely used among Cameroonian youths, especially francophone youths and across social classes. Camfranglais is today gaining grounds in schools and colleges and has contributed in enhancing the vocabulary of Cameroon English as many words of Camfranglais origin have found their way into mainstream Cameroon English lexicon. The language is popular music, sitcoms, popular literature, advertisements, etc.

Many researchers have carried out studies on this language phenomenon in Cameroon adopting different appellations. Some refer to this phenomenon as Camfranglais, others, Camspeak and yet others, Franglais. While the first two discuss a speech reality which involves the blend of Cameroonian indigenous languages, pidgin English, English and French, the last involves specifically the mixture of English and French words within the same utterance or text thereby giving a classical example of interference or language mixture. Ze Amvela (1989) distinguishes two types of Franglais: the invasion of French by English words and the invasion of English by French words. Commenting on the vast interference of Franglais in the speech of Cameroonians, Chia (1990: 111112) outlines three factors which are responsible for this interference:

1) The language user may resort to English words or expressions while in rapid conversation he is unable to remember the equivalents.

2) The term involved may be too technical and he will avoid using it for fear of being taxed as unnecessarily high-sounding in a context where his audience is not very learned and will not understand him which may instead lead to a breakdown in communication.

3) In the case of an English user of language, he may want to show off that he is proficient in French, which is considered a prestigious language in Cameroon.

Researchers who have tackled this language phenomenon have examined it from a global perspective with general statements to account for its form, structure and lexical characteristics. Prominent among these researchers are: Menang (1979), Mbangwana (1983), Ngome (1985), Tiayon (1985), Chia (1990), Ze Amvela (1989), Labatut (1994), Biloa (1999), Kouega (2003), Vakunta (2014), Kamdem (2015) etc. These studies, however, have scarcely discussed in clear terms if Camfranglais is a new language or a new speech form in Cameroon. 


\section{The Genesis of Camfranglais}

Although 'Camfranglais' is a fairly recent phenomenon as the various studies cited above seem to indicate, earlier studies on Pidgin English had already detected innovative activities within the language that augured the emergence of new social varieties of the language. Hence, Menang (1979) made reference to youthful forms of Pidgin English speech in which one found a mix of lexical items from Pidgin English, French and indigenous languages. In discussing what he referred to as 'emergent trends' in Pidgin English usage, Menang (1979, p. 116) reproduced the following short conversation between two young people, a boy and a girl, in a Victoria (Limbe) pub:

\section{-Girl: $\quad$ Wusai yu los so}

(Where have you been. You have been so missing).

-Boy: $\quad$ Sista, no bi na mi dis, spoil mi

(Sister, isn't this me? Spoil me)

This, of course, is not Camfranglais in its present sophistication, but it already indicated a certain speech novelty that was going to develop with time. Menang (ibid) drew attention to items such as "jam" and "spoil" which are old words to which the young people have given new meanings ("meet" and "give someone a treat" respectively). He also mentioned the introduction of the French word "swaré" (soirée) which was a fashionable replacement for "ivining" (evening). Menang (1979, p. 16) indicates clearly that "usually, these new meanings are known only to members of the group and thus they are able to keep non-members out of their chats".

Later on, Mbangwana (1983, p. 83) drew attention to the fact that Pidgin English was rapidly increasing its vocabulary by drawing items from French and home language (HL) sources. He pointed out that "Such an important contribution to the $\mathrm{CPE}$ vocabulary stock from French and indigenous sources clearly demonstrates that the form of CPE in terms of its lexical mix is being constantly enriched and expanded".

Tiayon (1985) and Ngome (1985) conducted more detailed studies on these emerging speech styles, drawing attention to the various processes through which new vocabulary items were derived and listed several newly coined words. At this time, the term "Camfranglais" had not yet been coined. Tiayon (1985) labelled the new speech form "Camspeak", while Ngome (1985) considered the new items as 'lexical renovations' in Pidgin English. The term "Camfranglais" did not emerge before the end of the eighties and the beginning of the nineties (Ze Amvela, 1989 and Chia, 1990).

In 1989, Ze Amvela (1989, p. 57), while reporting that some researchers believed that Camfranglais is a new language that would gradually replace Pidgin English, described the linguistic phenomenon in the following terms "From a purely linguistic point of view, Camfranglais is made up of a composite vocabulary which is usually expressed through Pidgin English grammar or French Grammar."

Biloa (1999, pp. 147-148), describes Camfranglais as the product of the cohabitation of numerous languages in Cameroon (Cameroonian languages, Pidgin English, French and English) and is popular among the unemployed, workers, hawkers and students. He considers it a hybrid form and refers to the code as "a new speech variety observed in Cameroon".

Kouega (2003) considers Camfranglais as a composite language developed consciously by secondary school students who share a number of linguistic codes; French, English, Pidgin English and some indigenous languages.

\section{Functions of Camfranglais}

The various studies under review are quite unanimous about who uses Camfranglais and what this code is used for.

When Menang (1979) observed what he termed an emerging trend in Pidgin English usage that can be thought of today as a harbinger of "Camfranglais", he reported in the first place that the new speech form was popular among young users of Pidgin English. He also reported that the main function of the new speech form was to keep adults and strangers out of the young people's chats. Subsequent studies (Ngome, 1985; Ze Amvela, 1989; Chia, 1990; Biloa, 1999 and others have come to confirm in the first place that Camfranglais is a peer-group phenomenon that does not extend to the wider language community. In other words, one can say that within the language community, there may be one or several Camfranglais speech communities. Ngome (1985), for instance, states that most of the new words in his corpus have fairly restricted in-group usage. They are found in the Pidgin English speech of young people who are mostly urban dwellers and are either students, hawkers, taxi drivers or "market-boys". 
Concerning its uses, the situation has hardly evolved since this linguistic phenomenon came into existence three decades or so ago. Menang (ibid) reported that the new variety of Pidgin English had a peer-group function.

The secondary function suggested here, that is, Camfranglais as a language for making fun among speakers and non-speakers, is indeed a very marginal one. Camfranglais is primarily a "secret code" that is used for communicating messages to chosen persons. If non-users of the code find it amusing, this is precisely because it is strange. One other thing that these studies have not highlighted so far is the fact that being a "secret code", "Camfranglais" is often used by delinquents and even criminals when they do not want "honest" people to know their naughty or devilish plans. Although the list of its uses is quite long (unemployed youths, students and pupils, hawkers and "market-boys", taxi drivers etc.), these groups do not use Camfranglais for communicating with nonmembers of their respective groups. Students, for instance, do not use it to talk to their teachers, parents or strangers; nor do taxi drivers and hawkers use it to address their customers. Whenever Camfranglais is used, the intention is almost always to exclude non-members of the group. Today, the situation has changed and there are strides towards giving Camfranglais more visibility and taking off the stereotype of language of delinquents. This is seen especially through the compilation of a Camfranglais dictionary (Kamdem, 2015) which constitutes a step towards the standardisation of the language, Vakunta's (2014) talk of the emergence of a hybridised literature including Camfranglais items in literary productions among others.

\section{Formal Characteristics of 'Camfranglais'}

The various studies under review focus primarily on three main formal features: word derivational and coinage processes in 'Camfranglais', utterance structural (syntactic) features and phonological and morpho-phonemic features.

Almost all the studies agree that the ever-growing vocabulary of 'Camfranglais' draws heavily from Pidgin English, French and Cameroon's indigenous languages (Ngome, 1985, Tiayon, 1985, Ze Amvela 1989, Chia, 1990, Biloa, 1999). Detailed descriptions of the various word derivational processes are found in the last three studies.

As concerns the structure of utterances in Camfranglais, various converging, though not identical views are held. Mendo Ze (1990) sees French syntax as the model on which Camfranglais utterances are built. These utterances, he writes, either obey the rules of French grammar or deliberately distort them. Ze Amvela (1989), Chia (1990) and Biloa (1999) draw attention to the fact that apart from French grammar, Pidgin English also sometimes provides the underlying structure of Camfranglais utterances. Chia's (1990) ten principles that are said to govern the building of utterances in this code are indeed enlightening. These principles appear more as new constructive devices than as destructive ones. Of these, the following are worth noting:

- The structure of each utterance reflects the deep-structure of one of its main source languages or one of the super-stratum languages;

- To render 'Camfranglais' difficult to understand, changes in deep structure are effected at points of semantic density;

- Key terms brought in from other languages do not have to obey the rules of the deep structure language;

- The pronunciation of borrowed items remains the same as in the source language;

- Coined words receive an invented pronunciation to avoid confusion.

One thing remains clear all along: Chia (1990) does not suggest that there is yet a grammar of Camfranglais in terms of a coherent system. The same seems true of phonology.

Nevertheless, Biloa (1999) goes on to attempt a phonological and morpho phonemic analysis of Camfranglais. He lists the various vowels, consonants and semivowels of the code. He draws vowels and consonant charts before proceeding to describe various morpho-phonemic processes. It is yet to be seen just how solidly this phonological system is built. But it may be too early to talk of a phonology of Camfranglais.

That notwithstanding, some of the conclusions drawn by Biloa (1999, p. 171) are interesting as they underscore the absence of consistency in the structure of Camfranglais utterances. He first writes:

«Au niveau de la morphosyntaxe, on peut noter que le temps, le genre, le nombre et le système pronominal du Camfranglais sont ceux du français ».

"As far as morphosyntax is concerned, it can be noted that the tense, gender, number and pronominal system of Camfranglais are those of French". (My translation)

He immediately points to the fact that French morpho-syntactic rules are not consistently applied: 
«Lorsque les verbes empruntés de l'anglais ou d'autres langues sont employés en Camfranglais, ils sont souvent morphologiquement invariables »

"When verbs borrowed from English or other languages are used in Camfranglais, they are often morphologically invariable" (My translation)

He goes on to confirm the presence in 'Camfranglais' of numerous utterances with an underlying Pidgin English structural features:

«Le Camfranglais a aussi recours aux structures du Cameroun pidgin-english. Les formes temporelles et aspectuelles du Cameroun pidgin english, qui sont invariables, abondent dans le Camfranglais ».

"Camfranglais also make use of Cameroon Pidgin-English structures. Temporal and aspectual forms of Cameroon Pidgin English, which are invariable, abound in the Camfranglais". (My translation)

In what seems to be a general conclusion, Biloa (1999, p. 172) suggests the existence of varieties of Camfranglais while still insisting on the multiple base of the code in general.

Certains variétés du Camfranglais ont plus recours à la syntaxe et au lexique du pidgin-english qu'à la syntaxe et au lexique du français. Ce fait suggère néanmoins, que le français et le pidgin-english constituent la fondation lexicale, morphologique et syntaxique sur laquelle le Camfranglais est bâti.

"Certain varieties of Camfranglais have more recourse to the syntax and lexicon of pidgin-english than to the syntax and lexicon of French. This fact nevertheless suggests that French and Pidgin English constitute the lexical, morphological and syntactical foundation on which Camfranglais is built".

(My translation)

With this review of the origins, functional features and formal characteristics of Camfranglais ended, one may proceed to draw from the various analyses some certainties and uncertainties about Camfranglais.

\section{Certainties and Uncertainties about 'Camfranglais'}

The various studies that have so far permitted the Camfranglais phenomenon to come into the limelight have discussed various characteristic features of this code. Some of these features have to do with its users and its uses. Others have to do with its form. A close examination of the discussions surrounding these features reveals that there are some on which most researchers tend to agree. These are referred to here as 'certainties'. There are others, however, about which there is hardly any consensus either because they are not clearly described or because it is too early to make any conclusive statement about them. These are the uncertainties. As the situation evolves and more light is shed on this speech phenomenon, some of the points which today appear to be shady will stand out more clearly.

\section{Certainties about 'Camfranglais'}

Chia (1990) outlines ten principles that can be said to govern usage in Camfranglais. These remain till date the most useful guide to usage in Camfranglais if one may talk about them in those terms. Without invalidating any of those principles, one may also suggest the following ten certainties about 'Camfranglais':

i. Camfranglais is a fairly recent speech phenomenon in Cameroon. Its emergence was signalled in studies conducted on Pidgin English is in Cameroon thirty years or so ago (Menang, 1979; Tiayon, 1985; Ngome, 1985). Its presence under the label of "Camfranglais" was confirmed by the end of the eighties (Ze Amvela. 1989; Chia, 1990);

ii. Camfranglais is the product of language contact. All the researchers agree on the fact that contact between some of the numerous languages used in Cameroon gave rise to this speech forms. However, more light still has to be shed on the specific circumstances that gave rise to its emergence since these languages have actually been in contact long before this emergence;

iii. The use of Camfranglais is not widespread. In fact, it is used within fairly restricted groups and circles that are dominated by young people (School and university campuses, street hawkers and market vendors, taxi drivers etc.);

iv. Camfranglais is generally part of the speech habits of bilinguals. When one examines the various principles outlined by Chia (1990), it becomes obvious that one needs to be familiar with at least two of its "source languages" to communicate effectively through this code. This, of course, does not exclude the fact that any one of the numerous languages used in Cameroon is a potential contributor to Camfranglais; 
v. Camfranglais functions basically as a secret code, the idea being to keep non-members of the group or circle out of the conversation. It is the medium par excellence of what may be referred to as the private domain of the youth (in which older people may not intrude);

vi. Camfranglais draws its vocabulary from the various languages in contact in Cameroon, notably from French, English and Pidgin English. The widely spoken home languages are all potential sources;

vii. The deep structure of Camfranglais utterances sometimes reflect that of French and sometimes that of Pidgin English. This feature is stressed in many studies (ZE Amvela, 1989; Chia, 1990; Biloa, 1999);

viii. Rule-breaking and/or rule-rewriting are some of the structural devices that are constantly used to keep the message inaccessible to the uninitiated. The language rules that are broken or rewritten are generally those of the languages that provide the deep structure of utterances. But it is easier to determine that a French rule has been broken or rewritten than that of Pidgin English. It would indeed appear that when a French rule is broken or rewritten, the intention is to make the structure of the utterance come closer to that of Pidgin English;

ix. Innovation is the rule rather than the exception in Camfranglais. This is necessary if the secret must be kept. For as uninitiated people become familiar with words and expressions that have been in use for long, it becomes necessary to coin new ones. Most of the processes of innovation are lexico-semantic, but others are morpho-phonemic;

$\mathrm{x}$. Because change and innovation are the rule in Camfranglais; the phenomenon frequently eludes accurate description and predictability.

These, of course, are by no means the only certainties about Camfranglais but they obviously summarise major usage trends.

\section{Uncertainties about Camfranglais}

The biggest uncertainty about 'Camfranglais' has to do with its status and typology. Because Camfranglais is a product of language contact and derives its resources from numerous sources; because its users are fairly welldefined groups and its uses (functions) are fairly restricted, its status as a language in its own right remains questionable. This situation therefore raises a number of questions such as the following:

Is Camfranglais a language, a language variety or several speech varieties in one?

Is it an autonomous system or does it comprise a number of co-existing systems?

Can it be said to have a phonology as Biloa (1999) suggests? How much of Camfranglais as we know it today will survive? Answers to these questions may not be immediately available but it would be interesting to see what the various studies already have to say.

\section{How Autonomous is Camfranglais?}

Much has been said about the fact that Camfranglais draws its lexical resources from various languages and that its structure is sometimes a reflection of French structure and sometimes that of Pidgin English. But nowhere is it clearly suggested that its speakers believe they are speaking a distinct language with its own norms that can be said to be different from those of the languages from which they draw their resources. Its users are drawn from various walks of life but it can hardly be said to have a clearly defined speech community. Besides, all its resources are traceable to various sources and cannot be said to have been integrated within a single system.

\section{Has Camfranglais Come to Stay}

This is another question whose answer remains uncertain. Ze Amvela (1989) cites some researchers as saying that Camfranglais is replacing Pidgin English. If that were really the case then the chances of the survival of Camfranglais for a reasonable length of time would be quite many. We may not forget that Pidgin English has been in use in Cameroon for several hundred years and there is hardly any real indication that it is being supplanted. Camfranglais indeed has come in to complement Pidgin English as a language of intimacy in certain circles. But it constitutes no threat to Pidgin English.

Another fact highlighted by the various studies is the fleeting nature of the new speech forms which have to be constantly renewed if the "secret" must be kept. This poses the question of the survival of Camfranglais as we know it today. 


\section{Conclusion}

It is certainly too early to provide a definitive answer to the question, "Is Camfranglais a new language"? This is largely because the phenomenon is a recent one and existing studies cannot be said to have been thorough. This phenomenon will have to be closely observed by linguists and socio-linguists over the next few decades or so before clear-cut answers can be provided. Nevertheless, from the present review of opinions, the following tentative conclusions may be drawn.

i. Camfranglais cannot be spoken of in terms of a new language that is distinct from all the other languages from which it draws its resources. In the first place, it does not constitute an autonomous system with its own norms which are recognised and respected as such by its users. Besides, in its deep structure, it is traceable not to one but to two languages that are recognised as distinct, that is, French and Pidgin English;

Camfranglais utterances are said to shift from one deep structure to the next and so far no suggestions exist that the two systems are undergoing a process of integration.

ii. Camfranglais thus seems to be a fairly complex phenomenon that comprises the use of more than one linguistic code and involves considerable internal variation. It would be useful and necessary to explore the possibility of the existence of two broad types of Camfranglais, one with a French deep structure and the other with a Pidgin English deep structure;

A close examination of the evolution of Camfranglais over the past three decades reveals that the version of Camfranglais with a Pidgin English deep structure actually preceded the French-based one. When in the early mideighties Camfranglais emerged, it was most popular in Douala, Cameroon's economic capital, where it was viewed as a characteristic way of speaking Pidgin English, among members of the lowly classes that were struggling for survival. It was the language of "débrouillardise" that gained popularity through the music of Lapiro de Mbanga who stood as a symbol of this new spirit and new generation of survivors and economic warriors (street hawkers, "market boys", taxi drivers etc.). All these people come to identify and distinguish themselves from the others by the variety of Pidgin English they spoke.

When this phenomenon rocked Douala, Camfranglais in its French (deep structure) version did not exist. It was only subsequently that students in the Yaounde University campuses, drawing inspiration from the Pidgin English version, developed a French-based version of Camfranglais. The two versions have coexisted even since then.

iii. When each broad type of Camfranglais is placed within the context of the base language, it looks more like a functional variety of that language than a new language. These functional varieties can be likened to jargons that are known to exist within languages without constituting new languages. This is referred to in French as "argot" which is defined as a speech form that is characteristic of a given social or professional group;

The reason behind the emergence of 'Camfranglais' seems to lend credibility to this view. Camfranglais arose from the desire of members of the various social/youth groups to communicate in the presence of their elders or the uninitiated without being understood by them. In this respect, it functions like any jargon of the underworld. In fact, Camfranglais is extensively used among criminal and juvenile delinquents in Cameroon today.

iv. Because linguists and socio-linguists have not yet had enough time to observe and study Camfranglais, hasty conclusions about this phenomenon have to be avoided. If it turns out that Camfranglais actually involves not one but two or more coexisting codes, then it will have to be studied further from code-switching and code-mixing perspectives. This will certainly permit a better understanding of the phenomenon;

v. Finally, it is not easy to predict the future of Camfranglais. It has emerged to further complicate the already complex linguistic situation in Cameroon. There are chances that it could last a while but it is not likely to remain the way it is today.

If it does last, and since innovation is the rule, there will continue to be internal variation as different social groups use it. It will also continue to change rapidly in time as one generation grows out of it and a new one emerges to continue the task of innovation. The likelihood that it could develop into a standardizable language is quite slim. It will no doubt influence usage in French, Pidgin English, or even the other languages. But is not likely to supplant any of them in a foreseeable future.

\section{References}

Biloa, Edmond (1999). 'Structure phrastique de Camfranglais : État de la question » in Echu, George and Allan W. 
Grundstrom eds. Official Bilingualism and Linguistic Communication in Cameroon. Peter Lang Publishing Inc. New York.

Chia, Emmanuel (1990). The New Speech forms of Rapidly Growing City: Pidgin French and Camfranglais in Yaounde' in Annales de la Faculté des Lettres et Sciences Humaines, Université de Yaoundé, VI, Nos, 1 et 2.

Kamdem, H. (2015) A Dictionary of Camfranglais. Frankfurt am Main: P. Lang Edition. https://doi.org/10.3726/978-3-653-05363-0

Kouega, Jean Paul (2003). 'Word formative processes in Camfranglais'. World Englishes, 22(4), 511-538. https://doi.org/10.1111/j.1467-971X.2003.00316.x

Kouega, Jean Paul (2003). 'Camfranglais: A novel slang in Cameroon schools'. English Today, 74, 19(2) Cambridge: Cambridge University Press. https://doi.org/10.1017/S0266078403002050

Mbangwana, Paul (1983). The Scope and role of Pidgin English in Cameroon' in Koenig, Edna L. Emmanuel Chia and John Povey eds. A Socio-Linguistic Profile of Urban Centres in Cameroon. Crossroads Press, Los Angeles, 79-92.

Menang, T. (1979). Trends in Cameroon Pidgin English Lexicology: A Study of Anglophone Speech. Unpublished Master's Degree dissertation, University of Yaounde.

Mendo, Z. G. (1990). Le français en Afrique noire francophone: Le cas du Cameroun, Paris : Editions ABC.

Ngome: Blasius (1985). Lexical Renovations in Cameroon Pidgin English. Unpublished "Maitrise" dissertation, University of Yaounde.

Tiayon, Charles L. (1985). Camspeak: A Speech Reality in Cameroon. Unpublished "Maîtrise" dissertation, University of Yaounde.

Vakunta, Peter (2014). Camfranglais: The Making of a New Language in Fouda's "Je parle Camerounais" and Fonkou's "Moi Taximan". The Journal of the Midwest Modern Language Association, 44(2), 93-110. https://doi.org/10.1353/mml.2011.0017

Ze Amvela, Etienne (1989), 'Reflections on Social Implications of Bilingualism in the Republic of Cameroon' in Epasa Moto, 1(1), June. University of Buea, 41-61.

\section{Copyrights}

Copyright for this article is retained by the author(s), with first publication rights granted to the journal.

This is an open-access article distributed under the terms and conditions of the Creative Commons Attribution license (http://creativecommons.org/licenses/by/4.0/). 